\title{
The Pathogenic White-Rot Fungus Heterobasidion parviporum Responds to Spruce Xylem Defense by Enhanced Production of Oxalic Acid
}

\author{
Nina Elisabeth Nagy, Harald Kvaalen, Monica Fongen, Carl Gunnar Fossdal, Nicholas Clarke, \\ Halvor Solheim, and Ari M. Hietala
}

Norwegian Forest and Landscape Institute, Ås, Norway

Submitted 8 February 2012. Accepted 11 July 2012.

\begin{abstract}
Pathogen challenge of tree sapwood induces the formation of reaction zones with antimicrobial properties such as elevated $\mathrm{pH}$ and cation content. Many fungi lower substrate pH by secreting oxalic acid, its conjugate base oxalate being a reductant as well as a chelating agent for cations. To examine the role of oxalic acid in pathogenicity of whiterot fungi, we conducted spatial quantification of oxalate, transcript levels of related fungal genes, and element concentrations in heartwood of Norway spruce challenged naturally by Heterobasidion parviporum. In the pathogen-compromised reaction zone, upregulation of an oxaloacetase gene generating oxalic acid coincided with oxalate and cation accumulation and presence of calcium oxalate crystals. The colonized inner heartwood showed trace amounts of oxalate. Moreover, fungal exposure to the reaction zone under laboratory conditions induced oxaloacetase and oxalate accumulation, whereas heartwood induced a decarboxylase gene involved in degradation of oxalate. The excess level of cations in defense xylem inactivates pathogensecreted oxalate through precipitation and, presumably, only after cation neutralization can oxalic acid participate in lignocellulose degradation. This necessitates enhanced production of oxalic acid by $\boldsymbol{H}$. parviporum. This study is the first to determine the true influence of white-rot fungi on oxalate crystal formation in tree xylem.
\end{abstract}

In both angiosperms and gymnosperms, pathogen challenge of sapwood results in the formation of a xylem defense boundary at the interface between colonized xylem and pre-existing healthy sapwood. These xylem defense boundaries, forming exclusively from living sapwood and referred to in the literature as the reaction zone (Schwarze et al. 2000; Shain 1967, 1971), CBL reaction zone, column boundary layer (Pearce 1996; Shortle and Smith 1990), compartmentalization walls 1 to 3 in the CODIT model (Shigo 1984), or pathological heartwood (Manion and Zabel 1979), show accumulation of antimicrobial compounds and cell necrosis. In addition, depending on the tree species, various other changes such as increased tissue water content, elevated $\mathrm{pH}$, and increased carbonate and

Corresponding author: A. M. Hietala; Telephone: +47 649490 49; Fax: +47 649480 01; E-mail: Ari.Hietala@Skogoglandskap.no

* The $e$-Xtra logo stands for "electronic extra" and indicates that one supplementary figure is published online. metal ion concentrations are common characteristics for defense xylem (Pearce 1991, 1996; Shain 1971; Smith and Houston 1994). Although several pathogens are able to colonize and eventually penetrate through this barrier, the strategies employed are poorly understood (Pearce 1991).

The Heterobasidion annosum species complex, one of the most important causative agents of wood decay in boreal coniferous forests, provides an example of pathogenic fungi that are able to challenge xylem defense boundaries. In Norway spruce (Picea abies (L.) Karst.), these fungi may cause an up to 10-mlong decay column in the heartwood of a mature tree. As a host response, a phenol-rich fungistatic reaction zone with an elevated $\mathrm{pH}$ and increased water and metal ion content is formed in the border area between healthy sapwood and colonized heartwood (Shain 1971). The phenols accumulating in the reaction zone are primarily composed of lignans, some of which have shown antifungal properties in bioassays (Johansson and Theander 1974; Shain 1971; Shain and Hillis 1971).

Microbial secretion of organic acids such as oxalic acid $\left(\mathrm{C}_{2} \mathrm{H}_{2} \mathrm{O}_{4}\right)$ may provide a benefit in various environments and perform essential roles in pathogenesis. Early in pathogenesis of several phytopathogenic fungi, oxalic acid may accumulate in infected tissue, leading to a decline in $\mathrm{pH}$ to 4.5 (Dutton and Evans 1996). The substrate $\mathrm{pH}$ modulation facilitates the activity of fungal extracellular enzymes that have $\mathrm{pH}$ optima below 5 (Punja et al. 1985). To weaken and degrade host cell walls, oxalic acid is produced in measureable amounts by the majority of brown rot fungi but in lesser amounts by white-rot fungi, the latter being commonly attributed to their concomitant production of oxalate decarboxylase, which degrades oxalate to formate and $\mathrm{CO}_{2}$ (Akamatsu et al. 1992). Regarding Heterobasidion spp., calcium oxalate is commonly formed during growth in alkaline culture media (Holdenrieder 1982; Volger et al. 1982), and calcium oxalate crystals have also been detected in the heartwood of Norway spruce colonized by H. annosum sensu lato (von Aufsess 1974).

Although the roles of oxalic acid for wood decay fungi are well covered from experiments utilizing liquid substrates (Dutton et al. 1993), there are very few studies on oxalic acid secretion by these fungi on natural lignocellulosic substrates (Mäkelä et al. 2002) and, to our knowledge, there are no reports about the role of oxalic acid in pathogenicity of wood decay fungi and their ability to colonize defense xylem. The purpose of this study was to examine whether $H$. parviporum, the most common species of the genus in northern Europe, employs oxalic acid to exploit pathological heartwood charac- 
terized by high $\mathrm{pH}$. This is accomplished by spatial quantification of crystallized- and water-soluble oxalate and element content in naturally infected stem xylem of Norway spruce showing different stages of reaction zone penetration, and by investigating the transcript level of fungal genes associated with the formation and degradation of oxalic acid.

\section{RESULTS}

\section{Reaction zone of Norway spruce shows} elevated $\mathrm{pH}$ and water content.

At stump level, all of the trees infected by $H$. parviporum displayed the characteristic olive to light-greenish reaction zone at the interface between sapwood and colonized heartwood (Fig. 1A and B). The coloration is derived from dense aggregates of phenolic substances that are accumulated in tracheids and ray cells in the zone.

In healthy trees, at the examined stem heights of 0 and $3 \mathrm{~m}$, the wood $\mathrm{pH}$ was 5.65 both in sapwood and throughout the heartwood (Fig. 2A). In diseased trees, at both heights, the wood $\mathrm{pH}$ was statistically significantly elevated in the reaction zone (mean $6.7 \pm 0.03, P$ values 0.016 and 0.018 ). In addition, the heartwood at stem base of diseased trees showed significantly lower $\mathrm{pH}$ than the respective healthy tissue $(P=0.012)$. In the other regions of the stem, no significant difference in wood $\mathrm{pH}$ was observed between healthy and diseased trees. In the inner bark, the $\mathrm{pH}$ had a mean value of 5.27 at 0 - and 3-m heights in both healthy and diseased trees (data not shown).

At ground level, the water content of the reaction zone and the outer part of the discolored wood in infected trees was, on average, in the range 90 to $60 \%$ dry weight (dw) and comparable with that observed in sapwood; whereas, at the 3-m height, the former two tissues showed water content below $20 \% \mathrm{dw}$, a level comparable with that observed in heartwood (data not shown).

\section{The fungal colony frontier interacting with the reaction zone is characterized by high concentrations} of precipitated and water-soluble oxalate.

The dark-brown to bluish heartwood layer inside the reaction zone (Fig. 1B and C), referred to as discolored wood, is characterized by abundant hyphal presence in tracheid lumens. By using polarizing filters in a light microscope, a belt of bright crystalline precipitates was observed at the colonization frontier within discolored wood (Fig. 1C). The precipitate occurred as irregularly granular aggregates and discrete crystals, some showing bi-pyramidal shape. All were without or with low birefringence and without coloration under polarized light. The crystal precipitates were located in the lumens of both tracheids and ray cells, and often in the vicinity of fungal hyphae (Figs. 1D and 3A). Cell lumens with phenolic aggregations

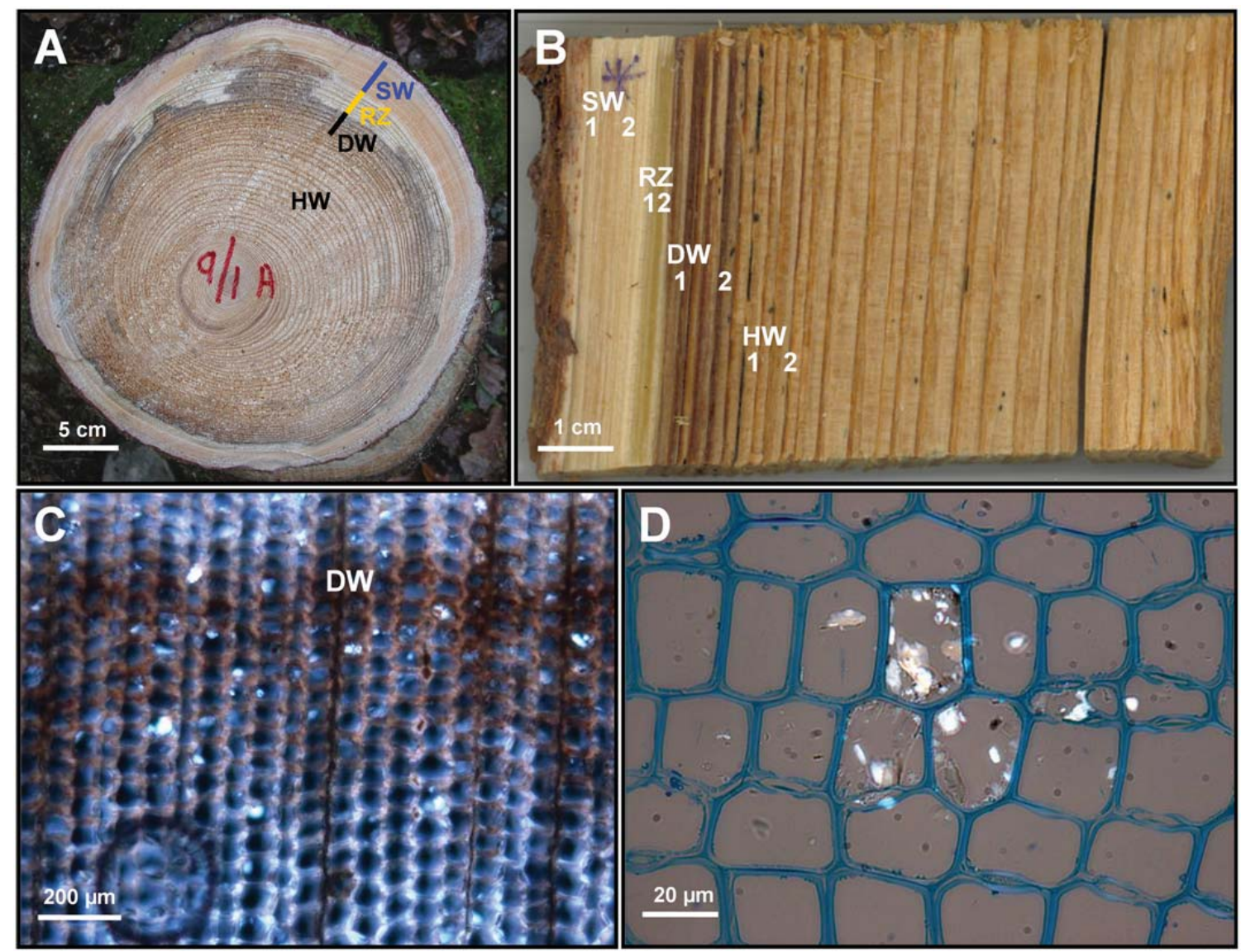

Fig. 1. Reaction zone dynamics and anatomical changes occurring in the stem of Norway spruce attacked by Heterobasidion parviporum. A, Transversal section of a stem disc sawn from the trunk of an infected tree at a height of $1 \mathrm{~m}$ above the ground. The intact reaction zone (RZ) is located between the healthy sapwood (SW) and bluish-brown discolored heartwood (DW), whose outer edge coincides with the fungal colonization border. Note the circumferential variation in fungal penetration depth into the reaction zone. B, Radial slice cut from a stem disc with decay. Two tangential strips comprising one to two annual rings of the different tissues were prepared from outer and inner regions of sapwood (SW1 and SW2), reaction zone (RZ1 and RZ2), discolored wood (DW1 and DW2), and heartwood (HW1 and HW2) of infected trees. Spatially corresponding tissue zones were cut from slices of healthy control trees. C and D, Precipitates of calcium oxalate as observed in polarized light. Crystalline precipitates accumulated in tracheid lumina at the edge of the DW region that displayed a high local concentration of fungal biomass. 


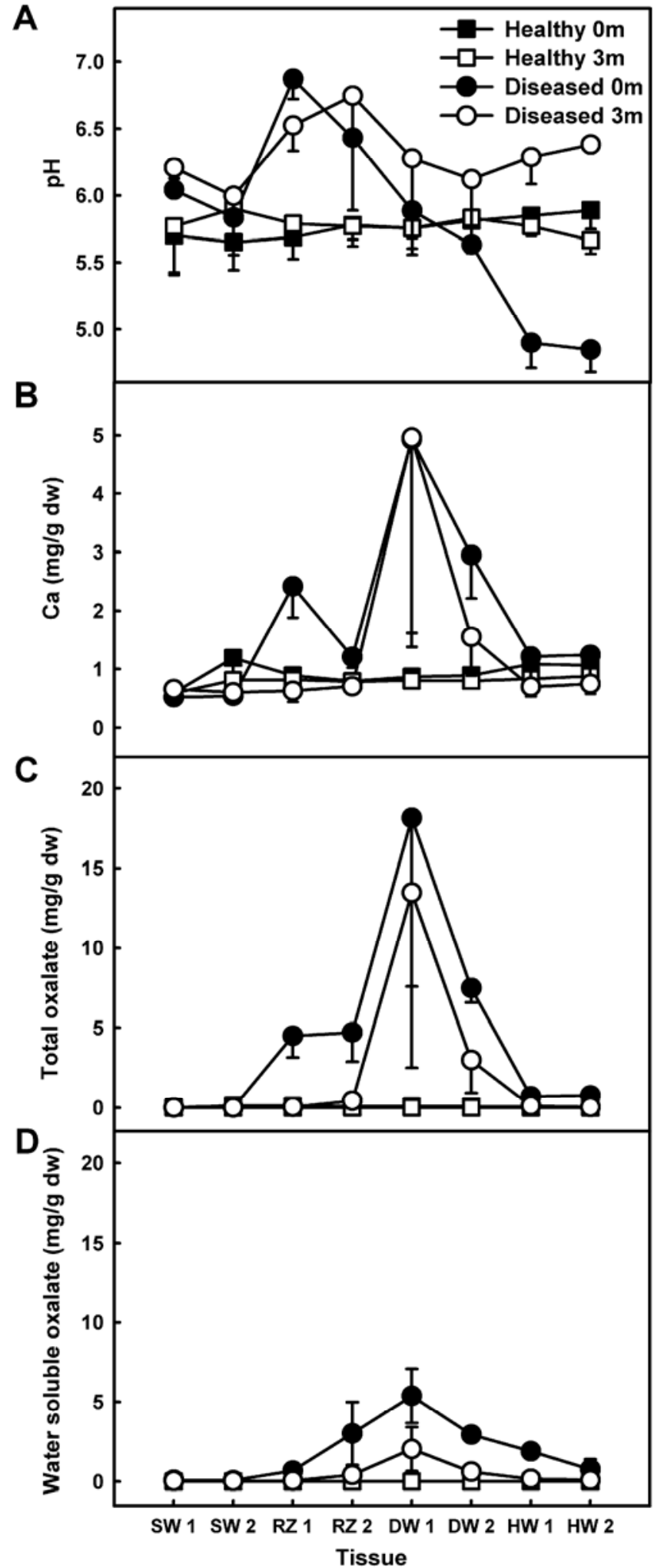

Fig. 2. pH, calcium, and oxalate amount in the different tissue (xylem) zones-sapwood (SW), reaction zone (RZ), discolored wood (DW), and heartwood (HW) - in stems from healthy and Heterobasidion parviporum-colonized Norway spruce trees (trees 5, 8, and 11) at stem base level $(0 \mathrm{~m})$ and $3 \mathrm{~m}$ above the ground. Data are means of three plants minus standard error (SE) or \pm SE. Two samples were prepared from inner and outer regions of SW, RZ, DW, and HW of diseased trees and spatially corresponding tissues of healthy trees. $\mathbf{A}, \mathrm{pH}$ values. $\mathbf{B}$, Concentrations of calcium (Ca), $\mathbf{C}$, Total oxalate (i.e., acid soluble). D, Watersoluble oxalate. and cell-wall-bordered pits also contained crystalline infill (Fig. 3B and C). Cells with crystalline precipitate seemed to be most common near the boundary of discolored wood adjacent to the reaction zone, a region with few phenolic occlusions in tracheid lumens. Using the X-ray microanalysis technique, these crystalline structures were identified to consist dominantly of calcium (Fig. 3D and E). We also identified crystalline aggregations that contained other cations such as potassium, magnesium, and manganese. The sound sapwood was devoid of crystals.

Total oxalate levels increased in the reaction zone, with a peak level at the outer edge of the discolored wood, compared with the almost undetectable concentrations in stem xylem of healthy trees at heights of 0 and $3 \mathrm{~m}$ (Fig. 2C). The discolored wood at ground level showed the maximum amount of total oxalate (mean for outer and inner discolored wood $=$ approximately $18 \mathrm{mg} / \mathrm{g}$ ), followed by discolored wood at the $3-\mathrm{m}$ height (approximately $14 \mathrm{mg} / \mathrm{g}$ ) and reaction zone at ground level (approximately $4 \mathrm{mg} / \mathrm{g}$ ). In the first and last case, the oxalate difference between diseased and healthy trees was statistically significant $(P$ values of 0.008 and 0.012 , respectively). The other analyzed regions, including the reaction zone at the 3-m height in diseased trees and spatially corresponding tissue in healthy trees, showed essentially similar oxalate values.

Water-soluble oxalate was not detectable in any of the tissues from healthy trees. In diseased trees, highest values were detected within the outer edge of the discolored wood. In addition, the adjacent reaction zone and inner margin of the discolored wood showed elevated oxalate levels at ground level (Fig. 2D). At peak areas (DW1), water-soluble oxalate constituted approximately 30 and $15 \%$ of the total content of oxalate at 0 and 3-m heights, respectively.

Total content of oxalate in the bark of healthy Norway spruce trees at heights of 0 and $3 \mathrm{~m}$ was $11.85 \pm 7.1$ and $8.1 \pm 2.5$ $\mathrm{mg} / \mathrm{g}$ ( \pm standard error $[\mathrm{SE}], n=3$ ), respectively. Corresponding values in diseased trees were $15.75 \pm 2.86$ and $19.55 \pm 4.62$ $\mathrm{mg} / \mathrm{g}( \pm \mathrm{SE}, n=3)$. The difference between healthy and diseased trees was not statistically significant.

\section{Metal cations co-accumulate with oxalate.}

Inductively coupled plasma (ICP) analysis of element distribution showed accumulation of calcium (Ca) (Fig. 2B) as well as potassium $(\mathrm{K})$, magnesium $(\mathrm{Mg})$, manganese $(\mathrm{Mn})$, and zinc (Zn) (data not shown) in the reaction zone, discolored wood, and heartwood in relation to the corresponding healthy control tissues (Fig. 2B). The differences between diseased and healthy trees were most pronounced for K: all three tissue types showed a statistically significant increase of $\mathrm{K}$ at stem heights of both 0 and $3 \mathrm{~m}(P=0.0001$ to 0.007$)$.

$\mathrm{Mg}$ values differed significantly between diseased and healthy trees in the reaction zone $(P=0.002)$ and discolored wood $(P=0.000005)$ at ground level but only in the reaction zone $(P=0.005)$ at the $3-\mathrm{m}$ height. Differences in Ca values were significant at ground level in the reaction zone $(P=0.004)$ but not quite in discolored wood $(P=0.059)$. No significant differences between diseased and healthy trees were found for $\mathrm{Mn}, \mathrm{P}$, and Zn (data not shown).

Regarding correlation between element and oxalate concentrations in xylem, product moment correlation coefficients between the acid-soluble portion (water-soluble oxalate subtracted from total oxalate) of oxalate and $\mathrm{Ca}, \mathrm{Mn}, \mathrm{Mg}, \mathrm{Zn}, \mathrm{K}$, and $\mathrm{P}$ were $0.95,0.86,0.76,0.68,0.1$, and -0.18 , respectively. Product moment correlation coefficients between water-soluble oxalate and $\mathrm{Ca}, \mathrm{Mn}, \mathrm{Mg}, \mathrm{Zn}, \mathrm{K}$, and $\mathrm{P}$ were $0.53,0.68,0.41,0.48$, 0.15 , and -0.02 , respectively.

Both healthy and diseased trees had higher concentrations of these six elements in bark than in wood (bark, data not shown), 
and the two tree groups showed similar values with no significant differences. Within the xylem, $\mathrm{P}$ had a unique distribution pattern, with a similar maximum concentration occurring both in healthy and diseased sapwood and in diseased heartwood at ground level, whereas the reaction zone showed the lowest concentration which, however, was not significantly different from the other regions.

\section{The balance between fungal synthesis and degradation} of oxalic acid shifts between reaction zone and heartwood.

In the laboratory experiment with milled heartwood and reaction zone tissues, the control heartwood sample showed acidsoluble oxalate at $0.24 \mathrm{mg} / \mathrm{g}$ and water-soluble oxalate at 0.07 $\mathrm{mg} / \mathrm{g}$, whereas in heartwood inoculated by $H$. parviporum, no oxalate was detected (Fig. 4A). The reaction zone showed a contrasting pattern: both total and water-soluble oxalate showed elevated values in tissue inoculated with the fungus (3.67 and $1.67 \mathrm{mg} / \mathrm{g}$, respectively) compared with the substrate without fungus (2.31 and $0.84 \mathrm{mg} / \mathrm{g})$. Regarding gene regulation, the oxalic-acid-producing oxaloacetase gene (OAH1) was strongly upregulated by $H$. parviporum in the reaction zone culture compared with the heartwood one (Fig. 4B). In contrast, the oxalate decarboxylases (OXD1 and OXD2) involved in degradation of oxalate showed upregulation in the heartwood compared with the reaction zone. The reference genes encoding enzymes active on pectin (PCL) and hemicellulose (XXH, GAL, and MAN) showed higher transcript levels in the heartwood culture than in the reaction zone culture (Fig. 4B). Regarding specificity of the primers, the melting point analysis produced a single melting point for each primer set (Table 1). Correspondingly, gel electrophoresis of the real-time polymerase chain reaction (PCR) products showed the presence of a single PCR product with the expected size for the pathogen (data not shown).

In Norway spruce trees naturally infected by $H$. parviporum, oxaloacetase (OAH1) was notably upregulated at the colony front restricting to reaction zone (Fig. 4C), whereas transcripts of oxalate decarboxylases were either absent or at a level beyond reliable quantification within the sampled decay column borders (data not shown). There was a positive correlation between the transcript levels of oxaloacetase and the level of total oxalate with a product moment correlation coefficient of 0.36 , both showing decreasing levels with increasing distance away from the reaction zone (Fig. 4C).

\section{DISCUSSION}

In both angiosperms and gymnosperms, sapwood challenge by heartwood-based pathogens induces accumulation of antimicrobial phenolics and elevation of tissue $\mathrm{pH}$ at the interface between intact and compromised xylem. This so-called reaction zone can be regarded as pathological heartwood because the event involves dying of the living ray parenchyma in the area mounting the defense response. Very few studies have focused on oxalic acid secretion by wood decay fungi on natural lignocellulosic substrates (Mäkelä et al. 2002); however, based on laboratory experiments with primarily liquid substrates, one role of oxalic acid is to acidify the extracellular environment to the optimal levels ( $\mathrm{pH} 2$ to 5) for cell-wall-degrading enzymes (Galkin et al. 1998; Shimada et al. 1997). To examine the role of oxalic acid in colonization of a reaction zone with a markedly elevated $\mathrm{pH}$, we profiled the spatial level of oxalate and regulation of oxalate-related genes by the pathogenic white-rot fungus $H$. parviporum in naturally colonized Norway spruce trees that display decay columns rising up to several meters within stem heartwood. Because the average annual vertical spread of the fungus is approximately $30 \mathrm{~cm}$ in Norway spruce heartwood, and stem infection in this pathosystem predominantly originates from root infection (Stenlid and Redfern 1998), we assume that the host-pathogen interaction at the interface between the reaction zone and colonized heartwood has been ongoing for well over a decade at the base of the examined stems whereas, at the $3-\mathrm{m}$ stem height, this process is younger; thus, the performed analysis at these two heights provides a temporal perspective on the interaction.

Excluding the presence of hyphae, the dark brown to blue heartwood tissue appearing adjacent to the reaction zone has similar features as the reaction zone wood, namely increased resistance to decay (Shain 1971), elevated $\mathrm{pH}$ and carbonate content (Johansson and Theander 1974), and phenolic lumen deposits in tracheids and rays (Hietala et al. 2009). This colonized tissue, referred to as discolored wood throughout the text, thus represents a compromised reaction zone. The oxalate amount and transcript levels of oxalic-acid-generating oxaloacetase of $H$. parviporum peaked within the outer edge of discolored wood. Furthermore, our laboratory experiment showed high induction of oxaloacetase and accumulation of oxalate in sterilized reaction zone tissue inoculated with $H$. parviporum. No oxalate accumulated in the heartwood culture, which showed high induction of genes encoding oxalate decarboxylases that decompose oxalate and genes encoding hemicellulases and pectinases. Taken together, the oxalate accumulation observed in a compromised reaction zone is evidently a fungal response to suboptimal conditions for feeding on wood cellwall components.

As previously noted for the reaction zones in Norway spruce (Shain 1971), and also shown for many other tree species (Pearce 2000; Safford et al. 1974; Shevenell and Shortle 1986; Smith and Houston 1994; Tattar et al. 1972), Ca, Mg, Mn, and $\mathrm{K}$ showed increased levels in the reaction zone and particularly in the neighboring discolored wood at the stem base, where these tissues had high water content. In solution, these elements are likely to be present as cations; and, at $\mathrm{pH}$ values prevailing in the reaction zone of Norway spruce, almost all oxalate will be present as the anion $(\mathrm{COO})_{2}{ }^{2-}$. Electroneutrality requires the balancing of the anionic charge with an equal cationic charge and, therefore, the observed co-accumulation of these elements with both water-soluble and acid-soluble oxalate is reasonable. $\mathrm{X}$-ray analysis data of the bi-pyramidshaped, weddellite-like $\left(\mathrm{CaC}_{2} \mathrm{O}_{4} \cdot 2 \mathrm{H}_{2} \mathrm{O}\right)$ crystals present in the discolored wood is compatible with the performed chemical analyses which showed that $70 \%(0 \mathrm{~m})$ to $85 \%(3 \mathrm{~m})$ of oxalate present in the tissue is not soluble in water. Upon growth on a Ca-rich medium in laboratory conditions, the production of $\mathrm{CaOx}$ crystals is a widespread phenomenon in white-rot fungi (Guggiari et al. 2012), Heterobasidion spp. included (Holdenrieder 1982; Volger et al. 1982). One role of oxalic acid is to acidify the extracellular environment to the optimal levels ( $\mathrm{pH} 2$ to 5) for cell-wall-degrading enzymes (Shimada et al. 1997). The significantly lower $\mathrm{pH}$ of stem base heartwood now observed in colonized trees compared with healthy xylem demonstrates that heartwood colonization by $H$. parviporum involves substrate acidification. The effect of oxalic acid on $\mathrm{pH}$ depends on the buffering agents present: because the pKa of phenolic compounds may be as low as 7 to 8 , the $\mathrm{pH}$ modulation effect of oxalic acid could be expected to be of minor importance in the reaction zone rays and tracheids occluded with polyphenols. However, the cell lumen impregnation level by phenolics is very variable in the reaction zone of Norway spruce; in some regions, all the tracheid lumens are occluded by polyphenols, the occluded tracheids forming a continuous tangential belt, whereas, in other areas, only the ray cells are phenol impregnated (Hietala et al. 2009). Oxalate crystals appeared to be most abundant in regions primarily de- 
void of phenolic occlusions in tracheid lumens, areas where chelation of excess cations by oxalate should be sufficient to modulate the local $\mathrm{pH}$.

We are aware of only one Heterobasidion study where oxalate has been observed at the reaction zone and heartwood interface in Norway spruce. The observation is reported by von
Aufsess (1974), who recognized crystals at the interface between reaction zone and heartwood colonized by Heterobasidion spp.; based on the reported shape and solubility properties, it seems likely that she examined calcium oxalate crystals. Oxalate accumulation at the interface between the reaction zone and discolored wood appears to be a common feature in
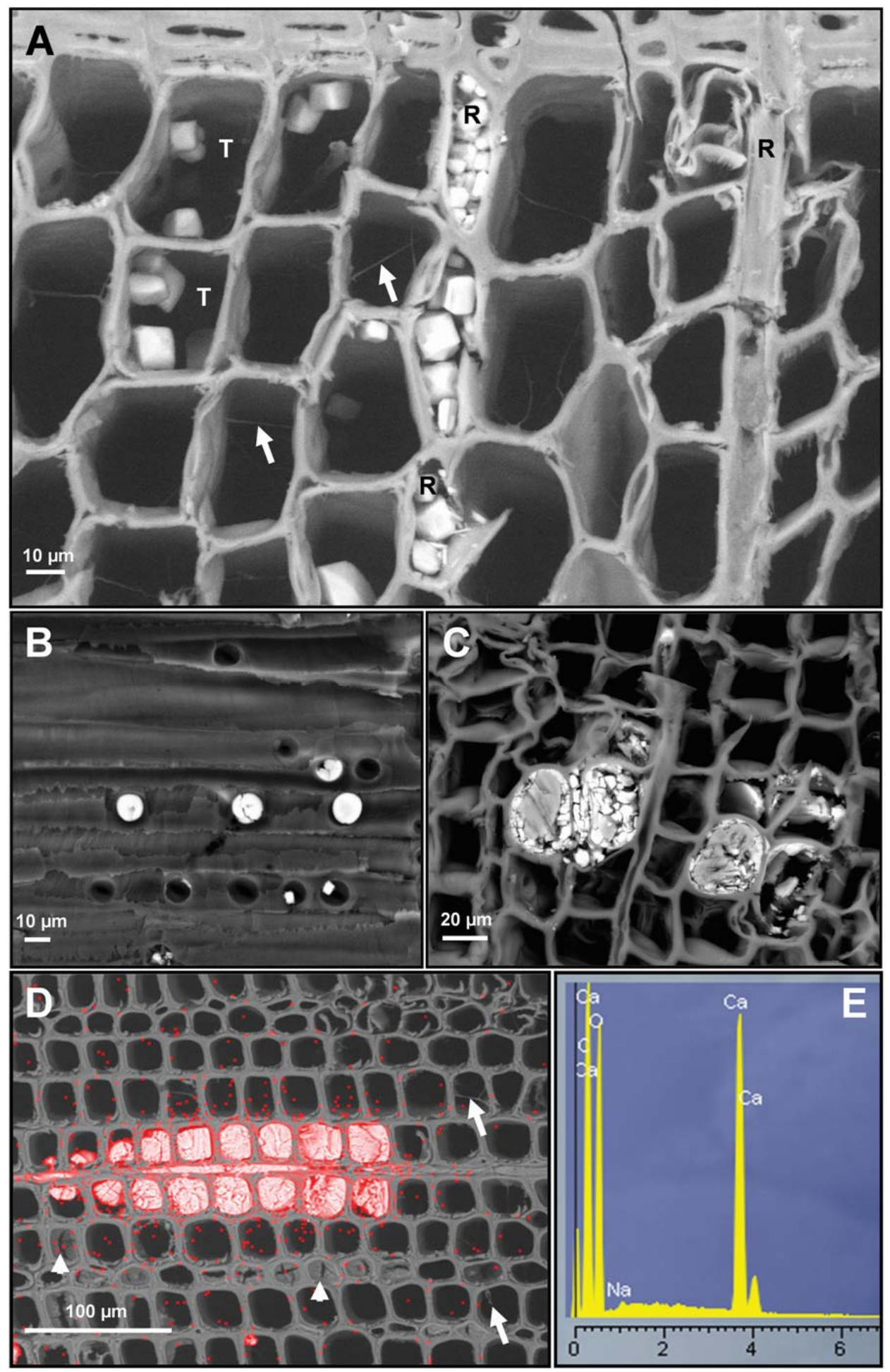

Fig. 3. Calcium oxalate precipitates in discolored heartwood of Norway spruce as visualized by scanning electron microscopy and X-ray microanalysis. A, Bi-pyramidal (seen from above) and prismatic calcium oxalate crystals in tracheids (T) and ray cells (R). Note the hyphal presence in tracheid lumina (arrows). B, Calcium oxalate aggregates (white particles) and crystals on bordered pits of ray cells. C, Tracheids containing granular precipitates of calcium, magnesium, and manganese together with phenolic occlusions. D, Scanning electron micrograph in back-scattered mode showing calcium signals as red spots. Crystals are seen as bright precipitates filling the lumina of tracheids and ray cells. Some of the cells are also filled with phenolic aggregates (arrowheads). Fungal hyphae are seen as gray threads across the lumina of some tracheids (arrows). E, Diagram from X-ray micro-analysis detecting calcium in the tracheid lumen shown in D. 
this pathosystem, as shown by our examination of 15 additional Norway spruce trees naturally infected by the pathogen (unpublished observations). It is logical that higher total oxalate levels were now recorded at the tree base than at a height of $3 \mathrm{~m}$, where the fungus has been interacting with the reaction zone for a shorter period of time. This difference was due to a higher level of dissolved oxalate at ground level than at $3 \mathrm{~m}$; this would suggest that immobilization of excess elements in cation-buffered cells is the initial role of oxalate at the early phase of host-pathogen interaction in the reaction zone. In general, the interaction between host tree and decay fungus in the reaction zone region has received little attention. In aspen with stem heart rot caused by the pathogenic white-rot fungus Phellinus igniarius, calcium oxalate crystals are most abundant within the decay column boundary restricted to discolored wood (Muhammad and Micko 1984). The commonality of oxalic acid production by pathogenic white- and brown-rot fungi upon challenge by xylem defense remains to be examined.

To initiate lignin degradation, Heterobasidion spp. secrete manganese peroxidases but lack the lignin peroxidases present in many other white-rot fungi (Olson et al. 2012). Manganese peroxidases (MnP) oxidize $\mathrm{Mn}^{2+}$ to $\mathrm{Mn}^{3+}$, using $\mathrm{H}_{2} \mathrm{O}_{2}$ as oxidant, and organic acids such as oxalic acid stimulate MnP activity by stabilizing the $\mathrm{Mn}^{3+}$, and produce diffusible oxidizing chelates (Glenn et al. 1986). Decay of reaction zone wood by $H$. parviporum is characterized by a prolonged period of selective decay, where concomitant action of lignin-degrading enzymes, hemicellulases, and pectinases enable preferential utilization of pectin and major hemicelluloses (Nagy et al. 2012). In addition to promoting lignin degradation by manganese peroxidases, oxalic acid has been proposed to act synergistically with polygalacturonase action by sequestering the pectin-associated $\mathrm{Ca}^{2+}$ ions to facilitate solubilization of protopectin and ready access of pectic acid to hydrolyzing enzymes (Green et al. 1991). The calcium oxalate aggregates in discolored wood were commonly associated with bordered pits. We consider it plausible that, upon colonization of the reaction zone, oxalic acid secretion by $H$. parviporum contributes eventually (if not in the initial colonization, where the excess cations present may precipitate a major portion of the oxalate formed) to fungal feeding through stimulation of $\mathrm{MnP}$ activity and solubilization of pectin through $\mathrm{Ca}$ sequestering from the pectin-rich middle lamella and adjacent primary cell wall, roles typical to oxalic acid upon wood decay by white-rot fungi (Mäkelä et al. 2010). Most likely, $H$. parviporum secreted oxalic acid plays these roles upon degradation of normal heartwood as well but, here, the generally low content of free cations and upregulation of oxalate decarboxylases prevent oxalate accumulation. Performance studies with oxaloacetase knock-out mutants would be needed to further clarify the roles of oxalate in $H$. parviporum and Norway spruce interaction.

\section{MATERIALS AND METHODS}

Tree and fungal material.

Material from nine mature Norway spruce trees growing in forest sites at Ås and Ski, two neighboring municipalities located in southeastern Norway, were used in the study. Six of the trees were naturally infected by $H$. parviporum. Three similar-sized trees with no pathological signs of infection were used as controls. The three control trees and three of the diseased trees (trees 5, 8, and 11), subjected to microscopy and examined for oxalate and element content and tissue $\mathrm{pH}$ at stem base and $3 \mathrm{~m}$ of height, were felled in September whereas the three diseased trees (trees 2, 3, and 4), subjected to transcript profiling at stem base, were harvested in June. After felling, 3-cm-thick stem disks were cut at stem base and at $3 \mathrm{~m}$ of height with a chain saw (Fig. 1A). Material reserved for RNA work was immediately placed in liquid nitrogen.

The presence of $H$. parviporum in infected trees was determined by fungal isolations made from each disc, followed by
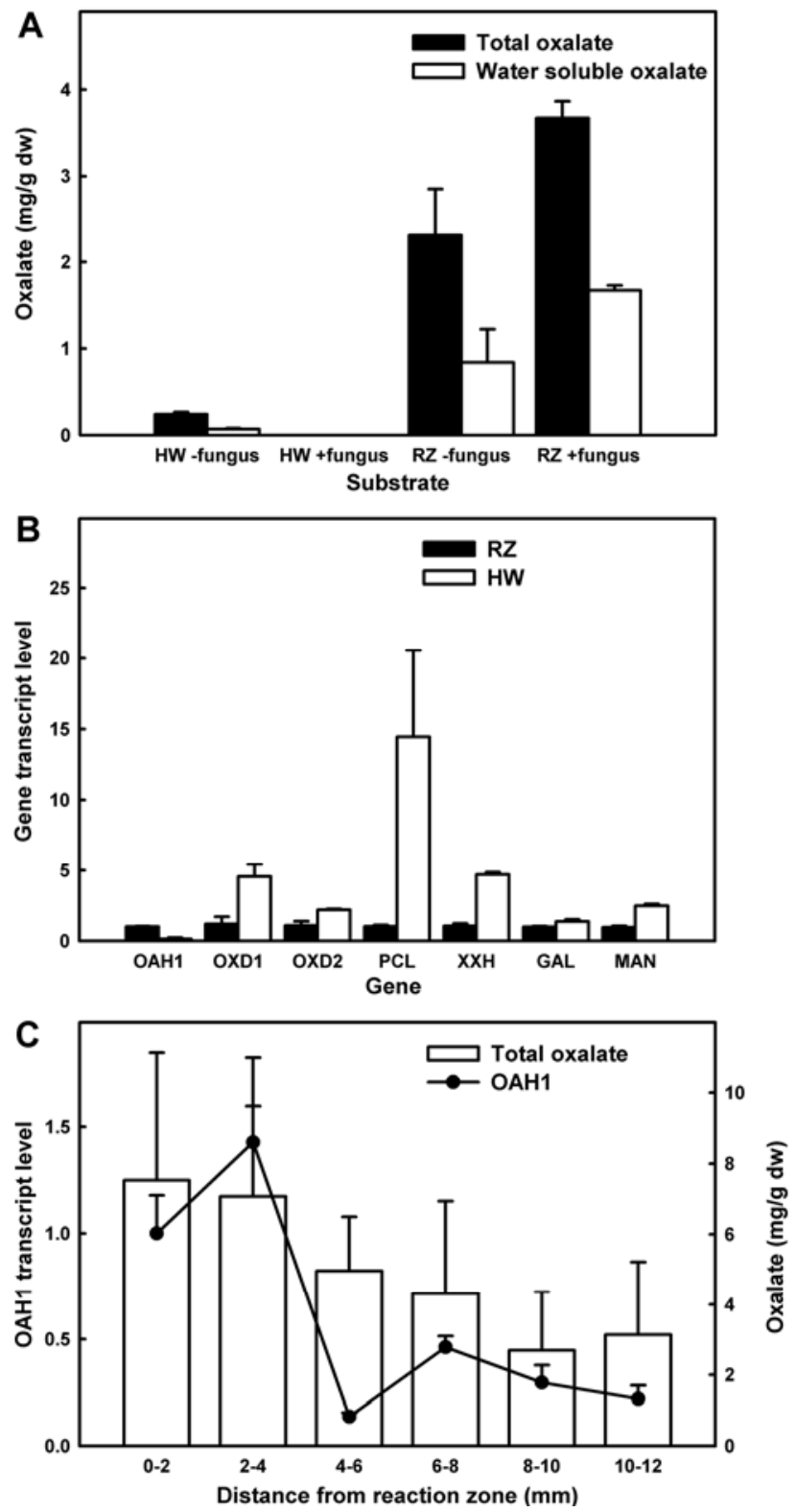

Fig. 4. Level of oxalate and regulation of related Heterobasidion parviporum genes upon colonization of milled wood under laboratory conditions and upon natural heartwood colonization of trees 2, 3, and 4. A, Levels of total and water-soluble oxalate when $H$. parviporum $(+)$ or a fungus-free growth medium (-) was used as inoculum in milled heartwood (HW) and reaction zone (RZ) tissues of Norway spruce and incubated for 3 weeks; B, corresponding transcript levels of $H$. parviporum genes synthesizing (OAH1, oxaloacetase) or catabolizing (OXD1 and OXD2, oxalate decarboxylase) oxalic acid, and transcript levels of reference genes encoding enzymes active on pectin (pectate lyase, PCL) and hemicellulose ( $\beta$-D-xylan xylohydrolase, $\mathrm{XXH}$; arabinogalactan endo- $\beta$-1,4-galactanase, GAL; $\beta$-mannosidase, MAN). Oxalate quantity and transcript level data are means of two or three biological replicates + standard error (SE), respectively. Normalized transcript levels in RZ were used as reference and defined as $1 \times$ expression level; transcript levels in HW are expressed as fold change over the reference level. C, Spatial profiles of total oxalate and transcript level of $H$. parviporum oxaloacetase (OAH1) upon natural colonization of three Norway spruce trees. Oxalate quantity and transcript level data are means of three biological replicates + SE. Normalized transcript levels at colony front were used as reference and defined as $1 \times$ expression level; transcript levels of the other samples are expressed as fold change over the reference level. 
standard mating tests with homokaryotic tester strains of $H$. parviporum and $H$. annosum sensu stricto (Korhonen 1978). Somatic incompatibility tests (Stenlid 1985) with the heterokaryotic isolates obtained from the six trees showed that each tree was colonized by a different genotype of the species.

The tree discs were stored at $-80^{\circ} \mathrm{C}$ until further processing. In the next phase, 1-cm-wide sectors were cut out with a knife and hammer, and 2-mm-long tangential strips of the different tissue zones were sampled with a dissecting knife. The strips were harvested from inner bark, sapwood, reaction zone, discolored wood, and inner heartwood (Fig. 1B). The material subjected to RNA work was prepared from frozen wood discs without allowing them to thaw.

\section{Inoculation experiment.}

To examine the ability of $H$. parviporum to produce oxalate in experimental wood xylem, an inoculation experiment was performed under laboratory conditions. Liquid Hagem $(0.5 \mathrm{~g}$ of $\mathrm{NH}_{4} \mathrm{NO}_{3}, 0.5 \mathrm{~g}$ of $\mathrm{KH}_{2} \mathrm{PO}_{4}, 0.5 \mathrm{~g}$ of $\mathrm{MgSO}_{4} \cdot 7 \mathrm{H}_{2} \mathrm{O}, 0.038 \mathrm{~g}$ of $[200 \mu \mathrm{M}] \mathrm{MnSO}_{4} \cdot \mathrm{H}_{2} \mathrm{O}, 0.8 \mathrm{ml}$ of $\mathrm{Fe}[\mathrm{II}] \mathrm{Cl}_{2} \cdot 4 \mathrm{H}_{2} \mathrm{O}[1 \%$ aqueous solution], and $5 \mathrm{~g}$ of malt extract per 1 liter of doubledistilled $\mathrm{H}_{2} \mathrm{O}$ ) was prepared as a medium for the inoculation experiment. Its $\mathrm{pH}$ was adjusted to 4.5 with $1 \mathrm{M} \mathrm{H}_{2} \mathrm{SO}_{4}$ and, after autoclaving, filter-sterilized thiamine $\mathrm{HCl}(0.1 \mathrm{mg}$ per 1 liter) was added. To prepare the inoculum, the heterokaryotic H. parviporum NFLI $87-257 / 1$ was grown on $2 \%$ malt extract agar for 3 weeks at $21^{\circ} \mathrm{C}$ in darkness. Conidiospores were collected from the cultures into liquid Hagem and the concentration was adjusted to 300,000 conidia $\mathrm{ml}^{-1}$ of liquid.

For the experiment, we used milled and $\gamma$-irradiation-sterilized reaction zone and heartwood tissue as substrate. The reaction zone material originated from a tree that was naturally infected by $H$. parviporum and that showed advanced decay in the heartwood and a prominent reaction zone. The heartwood material originated from a similar-sized healthy tree. The experimental system involved $1 \mathrm{~g}$ of material from the reaction zone or the heartwood tissue weighed in a petri dish $(9 \mathrm{~cm}$ in diameter). Each dish received $9 \mathrm{ml}$ of the liquid Hagem inoculum. Three replicates were prepared per substrate. The control treatment followed the same procedure but without fungus in the inoculum. The incubation period was 21 days at $21^{\circ} \mathrm{C}$ in darkness.

\section{Light microscopy detection of crystals.}

Specimens for microscopy were prepared from a strip of wood ( $1 \mathrm{~cm}$ thick, spanning from pith to the living sapwood), which was removed from each of the frozen stem discs. From the strip, 5-mm-wide wood blocks were cut out within the reaction zone and the discolored wood zone (DW). The specimens were fixed in paraformaldehyde $(2 \%)$ and glutaraldehyde
$(1.25 \%)$ in L-piperazine-N-N'-bis (2-ethane sulfonic) acid buffer $(50 \mathrm{mM}, \mathrm{pH} 7.2)$ for $12 \mathrm{~h}$ at room temperature. The wood blocks were either embedded in L. R. White resin and semithin cross-sections $(1.5 \mu \mathrm{m})$ cut using an LKB 2128 Ultratome (Leica Microsystems, Wetzlar, Germany) as previously described by Nagy and associates (2002) or frozen in Tissue-tec for cryo-sectioning ( $20 \mu \mathrm{m}$ thick) with a Leitz cryostat microtome at $-18^{\circ} \mathrm{C}$. Both resin and cryo-sections were dried onto superfrostPlus glass slides (Menzel-Gläzer, Germany). For routine observations, these sections were stained with Stevenel's blue (del Cerro et al. 1980). For assessment of crystal containment, polarized light microscopy was used for both resin sections and cryo-sections (Nagy et al. 2006).

\section{Scanning electron microscopy and X-ray microanalysis for identification of calcium in crystals.}

The morphology and element content of wood samples were examined in a Zeiss EVO 50 EP scanning electron microscope. For morphology studies, tissue blocks were fixed according to the same protocol as described for light microscopy. Following fixation, samples were frozen in Tissue-Tek (OCT Compound, Torrance, CA, U.S.A.) and the surface was polished using a cryo-microtome. The tissue blocks were then mounted onto carbon double-faced sticky tape on aluminum stubs, air dried, and carbon coated (using a Jeol JEE-4X Vacuum Evaporater). Energy-dispersive X-ray mapping of elements was performed on unfixated samples cut with a razor blade and mounted similarly. Acquisition of digital images, in both secondary and backscattered mode, was performed using a 4Q-BSD (4 Quadrant Backscattered Detector) and Link ISIS $300 \mathrm{X}$-ray analytical system (Oxford Instruments, Abingdon, U.K.).

\section{Determination of $\mathbf{p H}$.}

The $\mathrm{pH}$ of each sample was measured with a PHM229 Lab $\mathrm{pH}$ Meter and a combined $\mathrm{pH}$ Electrode (Radiometer Analytical S.A., Lyon, France). Milled wood samples $(0.1 \mathrm{~g})$ were mixed with water $(10 \mathrm{ml})$ and kept overnight at room temperature, after which the $\mathrm{pH}$ levels of the solutions were measured. The $\mathrm{pH}$ was corrected in relation to the dry weight of the material. This method follows a European Standard for $\mathrm{pH}$ in water extracts from soils (EN 13037).

\section{ICP analysis of elements.}

Extracts were obtained from ground wood samples (100 $\mathrm{mg})$ using diluted hydrochloric acid $(0.1 \mathrm{M}, 10 \mathrm{ml})$ in plastic tubes overnight. The solutions were filtrated through a Gelman Laboratory Acrodisc 25-mm Syringe Filter (with $1 \mu \mathrm{m}$ glass fiber membrane). Concentrations of $\mathrm{Ca}, \mathrm{K}, \mathrm{Mg}, \mathrm{Mn}, \mathrm{P}$, and $\mathrm{Zn}$ in the extracts were determined by ICP optical emission spectroscopy (Thermo Jarell Ash ICP-IRIS HR Duo). This is a modi-

Table 1. Primers used for transcript profiling of candidate genes

\begin{tabular}{|c|c|c|c|c|}
\hline \multirow[b]{2}{*}{ Gene $^{\mathbf{a}}$} & \multirow[b]{2}{*}{ Protein $\mathrm{ID}^{\mathrm{b}}$} & \multicolumn{2}{|c|}{ Amplicon } & \multirow[b]{2}{*}{ Forward/reverse primers $\left(5^{\prime}-3 '\right)$} \\
\hline & & Size (bp) & Melt $\left({ }^{\circ} \mathbf{C}\right)^{\mathrm{c}}$ & \\
\hline$\alpha$-Tubulin & 62388 & 88 & 82.8 & CATGGCTTGCGCTCTGTTGTA/AATGGTCCGCTTTGTCTTGATGAT \\
\hline Actin & 408649 & 113 & 82.9 & GCGCCTCCCGAGCGGAAGTA/CCAGGGCCCGACTCGTCGTA \\
\hline OAH1 & 39756 & 99 & 84.5 & TTGCTGCTGATGCGGGTGC/GAACTGGCTTAGGAGCGAGGGC \\
\hline OXD1 & 54400 & 131 & 81.6 & GCTTGCTCTCACTCCGCCCG/ACCAAACAATCATCGACCATCTGC \\
\hline OXD2 & 408838 & 105 & 83 & CAAAACTGATCGGTTCCAAGATGTCA/CCGGAAATTGTCTCATCGCTGAG \\
\hline PCL & 149208 & 91 & 80 & AATTCGCGCACGCCCTCCT/CATCGCGGGTGTTGATACCATCATTG \\
\hline XXH & 107773 & 93 & 81.5 & TGGATGTGAAGAACACGGGCAAG/CCTTCAACGGAGCAGGCGATG \\
\hline GAL & 37715 & 92 & 80.1 & CGAAATCCGTCGCCTCACCG/AATGAAGACGCCCGAGAAGAAGG \\
\hline MAN & 62665 & 110 & 86.7 & ACGTGACGGCGGAGGTGGAC/GCCGTGCGTGACGCTGAT \\
\hline
\end{tabular}

${ }^{\mathrm{a}} \mathrm{OAH} 1=$ oxaloacetase, $\mathrm{OXD} 1=$ oxalate decarboxylase $1, \mathrm{OXD} 2=$ oxalate decarboxylase $2, \mathrm{PCL}=$ pectate lyase, $\mathrm{XXH}=\beta$-D-xylan xylohydrolase, $\mathrm{GAL}=$ endo- $\beta$-1,4-galactanase, and MAN $=\beta$-mannosidase.

b Joint Genome Institute database.

${ }^{\mathrm{c}}$ Melting point. 
fied version of the method described by Schilling and Jellison (2007).

\section{Analysis of oxalate.}

Wood material from three of the infected trees, at 0 and $3 \mathrm{~m}$ of stem height, was subjected to oxalate analysis in sections from sapwood, reaction zone, discolored heartwood, and heartwood. Corresponding stem heights and zones were analyzed from healthy control trees. In addition, oxalate analysis was carried out on material from the inoculation experiment and for the colony front of the three trees subjected to transcript profiling.

The samples were heated overnight at $105^{\circ} \mathrm{C}$ and the weight losses were measured for the determination of the water content. Soluble and total amount of oxalate in 50 to $100 \mathrm{mg}$ of ground samples were extracted with $1.5 \mathrm{ml}$ of distilled water and $1 \mathrm{M} \mathrm{HCl}$, respectively, as described by Rahman and associates (2007). The suspension was heated to $100^{\circ} \mathrm{C}$ in a heating block for $18 \mathrm{~min}$. After cooling, the solution was centrifuged and filtrated into new vials. In addition, HCl-soluble oxalate was buffered with phosphate $(0.111 \mathrm{M})$.

Detection of oxalate was performed according to Schilling and Jellison (2004) using an Agilent high-performance liquid chromatograph with diode array detector. Separation was achieved on an Aminex HPX-87H column (Bio-Rad Laboratories, Richmond, CA, U.S.A.) with dimensions of $9 \mu \mathrm{m}, 300-$ by-7.8-mm i.d. at $\mathrm{pH} 1$ to 3 . Sulfuric acid (20 mM, $\mathrm{pH} 1.40)$ was used as the mobile phase, with a speed of $0.6 \mathrm{ml} \mathrm{min} \mathrm{mi}^{-1}$; the injection volume was $20 \mu \mathrm{l}$ and oxalate was detected at $210 \mathrm{~nm}$. With this method, oxalate is well resolved from other components in the extracts, and accurate quantification of oxalate concentrations is possible at 0.005 to $2 \mathrm{mM}$.

\section{RNA extraction and transcript profiling of genes related to synthesis and degradation of oxalic acid.}

Samples from heartwood naturally colonized by $H$. parviporum and reaction zone and heartwood samples from the inoculation experiment were ground using a Retsch 300 mill (Retsch GmbH, Haan, Germany) with liquid nitrogen chilled containers and steel beads. Total RNA was extracted from 100 $\mathrm{mg}$ of powder of the pulverized samples using the MasterPure Plant RNA purification kit (Epicentre Biotechnologies, Madison, WI, U.S.A.) according to the manufacturer's protocol that involves DNase I treatment to remove contaminating DNA. RNA was then quantified using micro-volume spectrophotometer NanoDrop 2000 (Thermo Scientific, Wilmington, DE, U.S.A.).

The annotated $H$. annosum database at DOE Joint Genome Institute (Walnut Creek, CA, U.S.A.) was used for obtaining the gene sequences of interest and, after BLAST verification at the National Center for Biotechnology Information GenBank, primers were designed for one oxaloacetase (OAH1), a gene synthesizing oxalic acid; two oxalate decarboxylases (OXD1 and OXD2), genes degrading its conjugate base oxalate; and candidate hemicellulases (XXH, GAL, MAN) and a pectinase (PCL). Actin and $\alpha$-tubulin were used as housekeeping genes. Gene-specific primers (Table 1) were designed using Primer3 (Rozen and Skaletsky 2000). Total RNA (500 ng per reaction) was reverse transcribed with oligo(dT) primers, using the TaqMan Reverse Transcription kit (number 8080234; Applied Biosystems, Carlsbad, CA, U.S.A.) in $50 \mu \mathrm{l}$ of reaction volume. PCR amplification was performed in a $25-\mu 1$ reaction volume using $3 \mu \mathrm{l}$ of a twofold-diluted cDNA solution as template, $12.5 \mu \mathrm{l}$ of $1 \times \mathrm{SYBR}$ Green master mix, and $200 \mathrm{nM}$ each primer. Reactions of qPCR were run using the 7500 Fast Real-time PCR system (Applied Biosystems) with the following cycling parameters: $50^{\circ} \mathrm{C}$ for $2 \mathrm{~min}, 95^{\circ} \mathrm{C}$ for $10 \mathrm{~min}$, and
40 cycles of $95^{\circ} \mathrm{C}$ for $15 \mathrm{~s}$ and $60^{\circ} \mathrm{C}$ for $1 \mathrm{~min}$. Two technical replicates were run for each sample. A control with no cDNA was run for each primer pair. Transcript levels were normalized against the geometric mean of actin and $\alpha$-tubulin cycle threshold values.

\section{Statistical design and analysis.}

The experiment was designed as a factorial with the following factors: treatment, tree within treatment, height along the stem, tissue type, and spatial position within tissue. All factors were considered fixed effects, except tree within treatment, which was considered to be a random effect, and interactions between fixed effects and random effects that were also random. The analysis of this mixed model was carried out with the Mixed procedure in the SAS System, using Satterthwaite's approximation for calculation of the degrees of freedom (Littell et al. 1996). Planned comparisons between least square means were made by use of the pdiff option for the lsmeans statement in the mixed procedure.

\section{ACKNOWLEDGMENTS}

We thank the Research Council of Norway (179482/130) and the Norwegian Forest and Landscape Institute (351119) for financing this study; T. Krekling and E. Ørmen for their assistance with sample processing and microscopy at the Electron Microscopy Laboratory, Department of Plant and Environmental Sciences, Norwegian University of Life Sciences (UMB); E. Stefanczyk for assistance in RNA extraction; and K. Korhonen for commenting on the manuscript.

\section{LITERATURE CITED}

Akamatsu, Y., Takahashi M., and Shimada, M. 1992. Cell-free extraction and assay of oxaloacetase from the brown-rot fungus Tyromyces palustris. J. Jpn. Wood Res. Soc. 38:495-500.

del Cerro, M., Cogen, J., and del Cerro, C. 1980. Stevenel's blue, an excellent stain for optical microscopical study of plastic embedded tissues. Microsc. Acta 83:117-121.

Dutton, M. V., and Evans, C. S. 1996. Oxalate production by fungi: Its role in pathogenicity and ecology in the soil environment. Can. J. Microbiol. 42:881-895.

Dutton, M. V., Evans, C. S., Atkey, P. T., and Wood, D. A. 1993. Oxalate production by Basidiomycetes, including the white-rot species Coriolus versicolor and Phanerochaete chrysosporium. Appl. Microbiol. Biotechnol. 39:5-10.

Galkin, S., Vares, T., Kalsi, M., and Hatakka, A. 1998. Production of organic acids by different white-rot fungi as detected using capillary zone electrophoresis. Biotechnol. Tech. 12:267-271.

Glenn, J. K., Akileswaran, L., and Gold, M. H. 1986. Mn(II) oxidation is the principal function of the extracellular Mn-peroxidase from Phanerochaete chrysosporium. Arch. Biochem. Biophys. 251:688-696.

Green, F., Larsen M. J., Winandy, J. E., and Highley, T. L. 1991. Role of oxalic acid in incipient brown rot decay. Mater. Org. (Berl.) 26:191213.

Guggiari, M., Bloque, R., Aragno, M., Verrecchia, E., Job, D., and Junier, P. 2012. Experimental calcium-oxalate crystal production and dissolution by selected wood-rot fungi. Int. Biodeterior. Biodegrad. 65:803809.

Hietala, A. M., Nagy, N. E., Steffenrem, A., Fossdal, C. G., Kvaalen, H., and Solheim, H. 2009. Spatial patterns in hyphal growth and wood degradation within Norway spruce stems colonized by the pathogenic white-rot fungus Heterobasidion parviporum. Appl. Environ. Microbiol. 75:4069-4078.

Holdenrieder, O. 1982. Production of crystals by Heterobasidion annosum (Fr.) Bref. (Fomes annosus P. Karst.) and some other wood-inhabiting fungi. Eur. J. For. Pathol. 12:41-58.

Johansson, M., and Theander, O. 1974. Changes in sapwood of roots of Norway spruce attacked by Fomes annosus. Physiol. Plant. 30:218-225.

Korhonen, K. 1978. Intersterility groups of Heterobasidion annosum. Commun. Inst. For. Fenn. 94:1-25.

Littell, R. C., Milliken, G. A., Stroup, W. W., and Wolfinger, R. D. 1996. SAS System for Mixed Models. SAS Institute Inc., Cary, NC, U.S.A.

Mäkelä, M., Galkin, S., Hatakka, A., and Lundell, T. 2002. Production of organic acids and oxalate decarboxylase in lignin-degrading white rot fungi. Enzyme Microb. Technol. 30:542-549. 
Mäkelä, M. R., Hildén, K., and Lundell, T. K. 2010. Oxalate decarboxylase: Biotechnological update and prevalence of the enzyme in filamentous fungi. Appl. Microbiol. Biotechnol. 87:801-814.

Manion, P. D., and Zabel, R. A. 1979. Stem decay perspectives-An introduction to the mechanisms of tree defence and decay patterns. Phytopathology 69:1136-1138.

Muhammad, A. F., and Micko, M. M. 1984. Accumulation of calcium crystals in the decayed wood aspen attacked by Fomes igniarius. IAWA Bull. n.s. 5:237-241.

Nagy, N. E., Franceschi, V. R., Solheim, H., Krekling, T., and Christiansen, E. 2002. Wound-induced traumatic resin duct formation in stems of Norway spruce (Pinaceae): Anatomy and cytochemical traits. Am. J. Bot. 87:302-313.

Nagy, N. E., Krokene, P., and Solheim, H. 2006. Anatomical-based defense responses of Scots pine (Pinus sylvestris) stems to two fungal pathogens. Tree Physiol. 26:159-167.

Nagy, N. E., Ballance, S., Kvaalen, H., Fossdal, C. G., Solheim, H., and Hietala, A. M. 2012. Xylem defense wood of Norway spruce compromised by the pathogenic white-rot fungus Heterobasidion parviporum shows a prolonged period of selective decay. Planta. doi:10.1007/s00425012-1664-4. Published online.

Olson, A., Aerts, A., Asiegbu, F., Belbahri, L., Bouzid, O., Broberg, A., Canbäck, B., Coutinho, P. M., Cullen, D., Dalman, K., Deflorio, G., van Diepen, L. T, Dunand, C., Duplessis, S., Durling, M., Gonthier, P., Grimwood, J., Fossdal, C. G., Hansson, D., Henrissat, B., Hietala, A., Himmelstrand, K., Hoffmeister, D., Högberg, N., James, T. Y., Karlsson, M., Kohler, A., Kües, U., Lee, Y. H., Lin, Y. C., Lind, M., Lindquist, E., Lombard, V., Lucas, S., Lundén, K., Morin, E., Murat, C., Park, J., Raffaello, T., Rouzé, P., Salamov, A., Schmutz, J., Solheim, H., Ståhlberg, J., Vélëz, H., de Vries, R.P., Wiebenga, A., Woodward, S., Yakovlev, I., Garbelotto, M., Martin, F., Grigoriev I. V., and Stenlid, J. 2012. Insight into trade-off between wood decay and parasitism from the genome of a fungal forest pathogen. New Phytol. 194:1001-1013.

Pearce, R. B. 1991. Reaction zone relics and the dynamics of fungal spread in the xylem of woody angiosperms. Physiol. Mol. Plant Pathol. 39:41-55.

Pearce, R. B. 1996. Antimicrobial defenses in the wood of living trees. New Phytol. 132:203-233.

Pearce, R. B. 2000. Decay development and its restriction in trees. J. Arboricult. 26:1-10.

Punja, Z. K., Huang, J.-S., and Jenkins, S. F. 1985. Relationship of mycelial growth and production of oxalic acid and cell wall degrading enzymes to virulence in Sclerotium rolfsii. Can. J. Plant Pathol. 7:109117.

Rahman, M. M., Niimi, M., and Kawamura, O. 2007. Simple method for determination of oxalic acid in forages using high-performance liquid chromatography. Jpn. Soc. Grassland Sci. 53:201-204.

Rozen, S., and Skaletsky, H. 2000. Primer3 on the WWW for general users and for biologist programmers. Methods Mol. Biol. 132:365-386.

Safford, L. O., Shigo, A. L., and Ashley, M. 1974. Gradients of element concentration in discolored and decayed wood of red maple. Can. J. For. Res. 4:435-440.
Schilling, J. S., and Jellison, J. 2004. High-performance liquid chromatographic analysis of soluble and total oxalate in $\mathrm{Ca}$ - and $\mathrm{Mg}$-amended liquid cultures of three wood decay fungi. Holzforschung 58:682-687.

Schilling, J. S., and Jellison, J. 2007. Extraction and translocation of calcium from gypsum during wood biodegradation by oxalate-producing fungi. Int. Biodeterior. Biodegrad. 60:8-15.

Schwarze, F. W. M. R., Engels, J., and Mattheck, C. 2000. Fungal Strategies of Wood Decay in Trees. Springer-Verlag, Berlin.

Shain, L. 1967. Resistance of sapwood in stems of loblolly pine to infection by Fomes annosus. Phytopathology 57:1034-1045.

Shain, L. 1971. The response of sapwood of Norway spruce to infection by Fomes annosus. Phytopathology 61:301-307.

Shain, L., and Hillis, W. E. 1971. Phenolic extractives in Norway spruce and their effects on Fomes annosus. Phytopathology 61:841-845.

Shevenell, B. J., and Shortle, W. C. 1986. An ion profile of wounded red maple. Phytopathology 76:132-135.

Shigo, A. L. 1984. Compartmentalization: A conceptual framework for understanding how trees grow and defend themselves. Annu. Rev. Phytopathol. 22:189-214

Shimada, M., Akamtsu, Y., Tokimatsu, T., Mii, K., and Hattori, T. 1997. Possible biochemical roles of oxalic acid as a low molecular weight compound involved in brown-rot and white-rot wood decays. J. Biotechnol. 53:103-113.

Shortle, W. C., and Smith, K. T. 1990. Decay column boundary layer formation in maple. Biodeterior. Res. 3:377-389.

Smith, K. T., and Houston, D. R. 1994. Metal concentrations in wood of sugar maple infected with sapstreak disease. Can. J. For. Res. 24:185188.

Stenlid, J. 1985. Population structure of Heterobasidion annosum as determined by somatic incompatibility, sexual incompatibility, and isoenzyme patterns. Can. J. Bot. 63:2268-2273.

Stenlid, J., and Redfern, D. 1998. Spread within the tree and stand. Pages 125-141 in: Heterobasidion annosum-Biology, Ecology, Impact and Control. S. Woodward, J. Stenlid, R. Karjalainen, and A. Hüttermann, eds. CAB International, Oxford.

Tattar, T. A., Shigo, A. L., and Chase, T. 1972. Relationship between the degree of resistance to a pulsed electric current and wood in progressive stages of discoloration and decay in living trees. Can. J. For. Res. 3:236-243.

Volger, C., Hesse, C., and Vogt, A. 1982. The occurrence of calcium oxalate crystals in Heterobasidion annosum (Fr.) Bref. Eur. J. For. Pathol. 12:59-70.

von Aufsess, H. 1974. Mikroskopische Erscheinungsbilder beim Holzabbau durch Fomes annosus (Fr.) Cooke. Eur. J. For. Pathol. 4:193-203.

\section{AUTHOR-RECOMMENDED INTERNET RESOURCES}

Joint Genome Institute Heterobasidion annosum database: genome.jgipsf.org/Hetan2/Hetan2.info.html

Primer3 database: frodo.wi.mit.edu/cgi-bin/primer3/primer3_www.cgi 